\title{
Growth, Yield and Yield Components of Canola Crop (Brassica napus) in El-Kharga Oasis New Valley as affected by bio, Nitrogen and Phosphorus Fertilization.
}

\author{
Mohamed, S.M. ${ }^{\text {' }}$ H.M. Mohamed ${ }^{1}$; H.M. Shahata ${ }^{2}$ and H.M. Ahmed ${ }^{2}$ \\ ${ }^{1}$ Soil and Water Department, Faculty of Agriculture, Assiut University. \\ ${ }^{2}$ Desert Research Center.
}

Received on: 14/11/2016

Accepted for publication on: 26/12/2016

\begin{abstract}
Field experiments were conducted for two successive seasons of 2007/2008 and 2008/2009 at the Experimental Research Station of the Desert Research Center at El-Kharga Oasis, the New Valley governorate. The object of this work was to study the effect of bio, nitrogen and phosphorus fertilizers on the growth, yield and yield components on canola crop. The results showed that the application of biofertilizers (Azotobacter and Bacillus megatherium caused significant increases in seed oil \% in seeds and total oil yield ( $\mathrm{kg} / \mathrm{fed})$ in the first season while plant height 1000 -seed weight and seed yield were not significantly affected by biofertilizers application. In the second season, plant growth yield and yield components were not significantly increased.

Nitrogen fertilization showed significant increases on all parameters studied in the two seasons. Data also showed that increasing nitrogen level from 30 to 90 $\mathrm{kg} \mathrm{N} /$ fed led to significant increases in plant height by 15.9 and $16.3 \%$ in the first and the second seasons respectively.

Increasing phosphorus level from 0 to $45 \mathrm{~kg} \mathrm{P}_{2} \mathrm{O}_{5} /$ fed resulted in significant increases in seed yield by $15.5 \%$ and $16.3 \%$ in the first and the second seasons respectively.
\end{abstract}

Keywords: Canola, Rapeseed, Canola Oil, N, P and biofertilizer, Oases.

\section{Introduction}

Rapeseed (canola, Brassica napus L.) is an important oilseed crop in the agricultural systems of many arid and semiarid areas where its yield is often restricted by water deficit and high temperatures during the productive growth. Canola seeds contain an average content of $38 \%$ oil, which may represent an agronomically sustainable choice (Tomm et al., 2010).

It contains $40-45 \%$ oil and $36-$ $40 \%$ protein. Canola oil has low content of erucic acid and glucosinolates, and high content of omega 3 and vitamin $\mathrm{E}$ which is also.considered one of the healthier oils for human consumption, being recognized by medicine as a functional food (Brown et al., 2008).

Biofertilizer is a material containing microorganism(s) added to a soil directly or indirectly to make certain essential elements available to plants for their nutrition. Various sources of biofertilizers include nitrogen fixers, phosphate solubilizing bacteria, plant growth promoting rhizobacteria, etc... (Shekh, 2006).

A number of differnt bacteria promote plant growth including Azotobacter spp., Azospirrillum spp., Pseudemonas spp., Bacillus spp. were 
used in inoculation of canola plants. The biofertilizer had significant and positive effect on plant height and yield of canola (Gupta and Samnotra, 2004; Turan and Sahin 2006).

Seed inoculation with different isolates of rhizosphere of different Brassica species showed significant increase in plant height (up to 5.5\%), stem diameter (up to $11.0 \%$ ), Number of branches (up to $35.7 \%$ ), number of pods/plant (up to 26.75), 1000-seed weight (up to $33.9 \%$ ), grain yield (up to $45.4 \%$ ) and oil content (up to $5.6 \%$ ) over the noninoculated control plants (Abd-El-Gawad et al., 2009).

Growth characteristics of canola such as plant height, number of brunches/plant, number of bods/plant, seed yield and oil content are positively related to soil $\mathrm{N}$ level (Ahmadi and Bahrani 2009). Mottalebipour and Bahrani (2006) found that increasing nitrogen application level as a vegetative growth stimulant, the number of secondary branches and accordingly the number of pods per plant increased. Also, Fatma and Wafaa, (2009) reported that increasing nitrogen fertilization significantly increased plant height, leaf area/plant, number of branches/plant, 1000-seed weight, seed yield/plant, seed and oil yield/fed., but decreased oil percentage in seeds. Similarly Fathy and Ahmed (2009) showed that as nitrogen fertilizer level increased, plant height, number of fruit/plant, 1000seed weight, seed weight/plant and protein content increased.

Many researchers have found that increasing of $\mathrm{N}$ fertilization rate to canola was of reverse effect on oil seed content. As mentioned previously nitrogen fertilizer application recorded positively response on seed yield. In this respect, Fathi et. al., (2002) observed that seeds from plots fertilized by $45 \mathrm{~kg} \mathrm{~N} / \mathrm{ha}$ contained $44.9 \%$ oil while seeds from these received $225 \mathrm{~kg} \mathrm{~N} / \mathrm{ha}$ contained $40.6 \%$ oil.

In general, high nitrogen amount reduced oil seed content; this was consistent with previous research works. This is probably due to the fact that presence of more available $\mathrm{N}$ in soil may delay plant maturity and increase seed filling period.

With regard to the effects of $P$ fertilization on canola, Brady and Weil (2002) showed that phosphorus is required in large quantities, especially in meristemic tissues, where cells are rapidly dividing and enlarging. Mohanty et al., (2006) found that phosphorus fertilization helps in energy storage, root development and early maturity of crops.

The objective of this research was to study the effects of biofertilizer, nitrogen and phosphorus fertilizers on the growth, yield and yield components of canola under El-Karga Oasis conditions.

\section{Materials and Methods}

\section{Experimental sites and soil sampling:}

The experimental field was conducted at the experimental research station of the Desert Research Center (DRC) at El-Kharga Oasis, New Valley, Egypt.

This study was carried out for two successive winter seasons of $2007 / 2008$ and 2008/2009. Completely randomized design (CRD) for field experiments with three replications for each treatment was employed. 
The experimental soil was sampled using the composite sample technique from the surface soil layer and sub-surface $(0-30 \mathrm{~cm}$ and 30-60 $\mathrm{cm})$ just to define what the initial physical, chemical, and nutritional status prior to field preparation for the cultivation of any of the two crops. Some physicael and chemical properties of the studied soil before cultivation in El-Kharga Oasis, the New Valley are presented in Table (1). Analyses were accomplished according to Page, et al., 1984 and Klute, 1986.

Table 1. Some chemical and physical properties of Soil prior cultivation in ELkharga Oasis the New Valley.

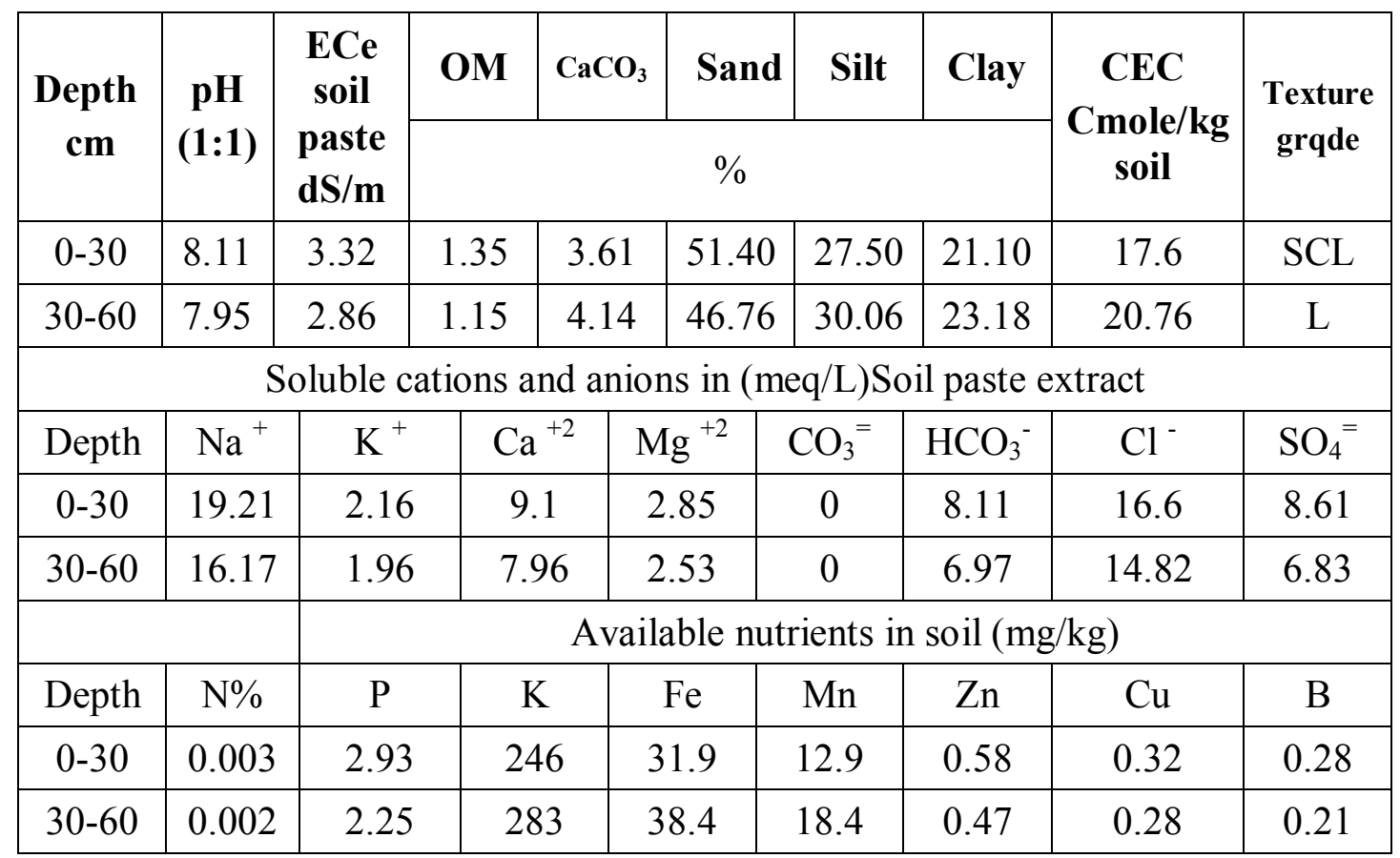

$\mathrm{SCl}=$ Sandy clay loam

$\mathrm{L}=$ Loam

\section{2- Experimental fields and fertil- izer treatments:}

The experimental field is intended to be nourished with the application of $10 \mathrm{~m}^{3}$ of welldecomposed organic manure at the time of land preparation. This was practiced for both adopted crops after which the land was to be ploughed two times with the second going perpendicular to the first plowing. The field was to be shaped into furrows at the spacing of 12 furrows $/ 7 \mathrm{~m}$ (about $60-\mathrm{cm}$ furrows). Afterwards,
$3.0 \times 3.5 \mathrm{~m}^{2}(1 / 400$ feddan $)(1$ feddan $=$ 0.42 hectar) experimental plots were formed for the layout of the experimental field plots for both crops.

The applied treatments included 2 biofertilizer treatments x $3 \mathrm{~N}$ levels $\mathrm{x} 3 \mathrm{P}$ levels x 3 replications for a sum of 54 experimental units. In the external fringe around the experimental layout, there was a protection zone to achieve true responses of the plants to the applied treatments and avoid the effect of advection of the surrounding ecological system. 
Canola Pactol variety was used at the rate of $5 \mathrm{~kg}$ seeds $/$ fed. The seeds for canola were bought from the Seed Propagation Unit of the Field Crops Institute of the Agricultural Research Center, at Giza Research Station, Giza governorate.

Canola, thinning took place when the seedlings reached the height of 5-8 cm high above the soil surface, i.e. at the age of about 20 days from emergence. Two plants were left per hill for a population density of about 56,000 plants/fed. Generally, seedling thinning was achieved during the soil surface hand hoeing which is attained either to mulch the soil surface by breaking the continuity of the capillary tubes, or to control weeds in the field.

All field plots received a basal dose of micronutrients ( $\mathrm{Fe}, \mathrm{Mn}, \mathrm{Cu} \&$ $\mathrm{Zn)} 0.5 \%$ solution sprayed onto the aerial parts of the plants during the rapid vegetative growth (shooting stage). The doses were applied on march $5^{\text {th }}, 2008$ and march $2^{\text {nd }}, 2009$ in the first and the second seasons respectively.

\section{3- Fertilization treatments:}

\section{3-1 Biofertilizer:}

A solution containing a mixture of two inoculants; one soil free-living atmospheric nitrogen fixer of Azotobacter and the other one soil freeliving phosphorus dissolving bacteria of Bacillus megatherum (PDB) was recruited for the purpose of this research. These two inoculants + the contents of $2 \mathrm{~kg}$ of sugar cane mollase were all thoroughly mixed with 100 liters of irrigation water. This quantity was intended for soil application at two doses. Therefore, half of this amount was used at each spray time.
The solution containing the biological mixture was applied in the vicinity of the plants during the start of the rapid vegetative growth using a backcarried sprayer. The application took place on December $12^{\text {th }}$ and $19^{\text {th }}$, 2007 and decmber $2^{\text {nd }}$ and $10^{\text {th }}, 2008$. This application was testified against a control treatment or no application, so the treatments in this regard are control (no application) versus the application (two treatment levels); Bio vs. no Bio.

\section{3-2 Nitrogen fertilization:}

The application of Nitrogen fertilizer took place on November $30^{\text {th }}$, 2007 and January $1^{\text {st }}, 2008$ in the first season and November $25^{\text {th }}$ and December $29^{\text {th }}, 2008$. Owing to the essentiality of $\mathrm{N}$ to plant growth, no control treatment was included among $\mathrm{N}$ applied levels. Nevertheless, $\mathrm{N}$ was applied at three levels 30 , 60, $90 \mathrm{~kg} \mathrm{~N} /$ fed.

\section{3-3 Phosphorus fertilization}

\section{treatments:}

This application took place on November $12^{\text {th }}, 2007$ and November $5^{\text {th }}, 2008$ for canola. These fertilization treatments were achieved at the levels of $0,15,45 \mathrm{~kg} \mathrm{P}_{2} \mathrm{O}_{5} /$ fed which were testified versus a control; i.e. three treatment levels.

\section{3-4 Plant sampling and meas- urements:}

\section{3-4-1 Measurements:}

1. Plant height $(\mathrm{cm})$.

2. 1000-seed weight $(\mathrm{g})$ at harvest.

3. Total seed yield per fed using the yield per 1square meter basis, then separating the seeds and weighing them, then calculating the yield per fed by multiplying by the appropriate factor of $4200 \mathrm{~m}^{2} / \mathrm{fed}$. 
4. For canola, was harvested after 150 days of age (from emergence) on April 15 $5^{\text {th }}, 2008$ and April $7^{\text {th }}$, 2009.

\section{3-4-2- Plant measurements}

During harvest: five-plant samples were taken from each experimental unit and the dry weight was recorded, then total seed weight and 1000-seed weight were recorded. The straw yield, seed yield, biological yield, and the weight of 1000-seed yield were recorded.

\section{3-5 Statistical analysis and ma- nipulations:}

\section{3-5-1 Analysis of variance:}

All obtained data were subjected to statistical analysis to exhibit the influences of the applied treat- ments on the measured plant and soil characteristics and traits. The splitsplit plot technique was used in three replications assigned to each experimental treatment combination according to Gomez and Gomez (1986). The biofertilization treatment occupied the grand main treatment which was randomly assigned to the three replicates. Then each main was split into the three submein level of $\mathrm{N}$ treatment which thus occupied the submain experimental units that were randomly assigned to the three subunits. The subunits, were then split into the three subunits for the random distribution of the three levels of $P$. the total number of experimental units becomes 54 plots as follows:

\begin{tabular}{|c|c|c|}
\hline Bio fertilization & $=$ With vs. Without Bio & $=2$ levels \\
\hline $\mathrm{N}$ fertilization & $=30$ vs. 60 vs. $90 \mathrm{~kg} \mathrm{~N} / \mathrm{fed}$ & $=3$ levels \\
\hline P fertilization & $=$ zero vs. 15 vs. $45 \mathrm{P}_{2} \mathrm{O}_{5} /$ fed. & $=3$ levels \\
\hline Replication & $=$ & $=3$ reps. \\
\hline Total plots & $=2 \times 3 \times 3 \times 3$ & $=54$ plots \\
\hline
\end{tabular}

The analysis of variance (ANOVA) was calculated to verify whether the differences among the treatments were significant or not (Gomez and Gomez, 1986). The least significant difference (LSD) at 5\% level of significance was recruited to differentiate every two significant means.
With Bio

$30 \mathrm{~N}-0 \mathrm{P}_{2} \mathrm{O}_{5}$

$30 \mathrm{~N}-15 \mathrm{P}_{2} \mathrm{O}_{5}$

$30 \mathrm{~N}-45 \mathrm{P}_{2} \mathrm{O}_{5}$

$60 \mathrm{~N}-0 \mathrm{P}_{2} \mathrm{O}_{5}$

$60 \mathrm{~N}-15 \mathrm{P}_{2} \mathrm{O}_{5}$

$60 \mathrm{~N}-45 \mathrm{P}_{2} \mathrm{O}_{5}$

$90 \mathrm{~N}-0 \mathrm{P}_{2} \mathrm{O}_{5}$

$90 \mathrm{~N}-15 \mathrm{P}_{2} \mathrm{O}_{5}$

$90 \mathrm{~N}-45 \mathrm{P}_{2} \mathrm{O}_{5}$
Without Bio

$30 \mathrm{~N}-0 \mathrm{P}_{2} \mathrm{O}_{5}$

$30 \mathrm{~N}-15 \mathrm{P}_{2} \mathrm{O}_{5}$

$30 \mathrm{~N}-45 \mathrm{P}_{2} \mathrm{O}_{5}$

$60 \mathrm{~N}-0 \mathrm{P}_{2} \mathrm{O}_{5}$

$60 \mathrm{~N}-15 \mathrm{P}_{2} \mathrm{O}_{5}$

$60 \mathrm{~N}-45 \mathrm{P}_{2} \mathrm{O}_{5}$

$90 \mathrm{~N}-0 \mathrm{P}_{2} \mathrm{O}_{5}$

$90 \mathrm{~N}-15 \mathrm{P}_{2} \mathrm{O}_{5}$

$90 \mathrm{~N}-45 \mathrm{P}_{2} \mathrm{O}_{5}$ 


\section{Results and Discussion}

Effect of fertilization treatments bio, $N$ and $P$ on plant growth, yield and yield components of canola:

Data in Table (2) summarize the effect of biofertilizers treatments (Azotobacter and Bacillus megatherium) on growth, yield and its components of canola during the two successive winter seasons of 2007-2008 and 2008-2009. The statistical analysis of obtained data show that the application of biofertilizers significantly increased oil \% in seed and oil yield (kg/fed.) in the first season. Plant height, 1000-seed weight and seed yield were not significantly affected by biofertilization either in the first or in the second season.

Naderifar and Daneshian (2012) found that biofertilizers (Azotobacter and Azospirillium) inoculation had significant effect on seed number per silques, number of silques per plant, seed yield, 1000-seed weight and seed yield of canola plants. Inoculation with penicillium bilgi, Bacillus thuringiensis and phosphate solubilizing rhizobacteria increase vegetative growth and seed yield of canola (Freitas et al., 1997).

Table 2. Effect of bio fertilization treatments on yield and its components of canola during 2007-2008 and 2008-2009 growing seasons.

\begin{tabular}{|c|c|c|c|c|c|}
\hline \multirow{2}{*}{ Bio fertilizer } & $\begin{array}{c}\text { Plant } \\
\text { height } \\
\text { (cm) }\end{array}$ & $\begin{array}{c}\text { 1000- seed } \\
\text { weight }(\mathbf{g})\end{array}$ & $\begin{array}{c}\text { Seed yield } \\
\text { (kg/ fed.) }\end{array}$ & $\begin{array}{c}\text { Oil } \\
\text { in seeds } \\
\text { (\%) }\end{array}$ & $\begin{array}{c}\text { Oil yield } \\
\text { (kg/ fed.) }\end{array}$ \\
\cline { 2 - 6 } & \multicolumn{5}{|c|}{$2007-2008$ season } \\
\hline Without bio & 132.2 & 3.94 & 824.4 & 38.71 & 319.1 \\
\hline Bio fertilizer & 133.4 & 3.98 & 832.3 & 40.06 & 329.8 \\
\hline F. test & N.S. & N.S. & N.S. & $*$ & $*$ \\
\hline \multicolumn{7}{|c|}{$2008-2009$ season } \\
\hline Without bio & 132.2 & 3.95 & 823.9 & 38.39 & 316.3 \\
\hline Bio fertilizer & 134.1 & 4.00 & 836.0 & 39.68 & 331.7 \\
\hline F. test & N.S. & N.S. & N.S. & N.S. & N.S. \\
\hline
\end{tabular}

Data present in Table (3) show the effect of nitrogen fertilization at three rates: 30,60 and $90 \mathrm{~kg} \mathrm{~N} /$ fed on growth, yield and yield components of canola during the two growing winter seasons of 2007-2008 and 2008-2009. In general, nitrogen fertilization resulted in significant increases in all parameters studied in the two seasons. Data also, show that increasing nitrogen level from 30 to $90 \mathrm{~kg} \mathrm{~N} / \mathrm{fed}$. led to significant increases in plant height by 16.32 and $15.91 \%$ in the first and in the second season respectively. On the other hand treatment of $90 \mathrm{~kg} \mathrm{~N} / \mathrm{fed}$ significantly increased the 1000 -seed weight by $24.02 \%$ and $24.20 \%$ in the first and in the second season respectively compared to the $30 \mathrm{~kg} \mathrm{~N} / \mathrm{fed}$. treatment. Increasing the applied nitrogen rate from 30 to $90 \mathrm{~kg} \mathrm{~N} / \mathrm{fed}$. was of highly significant influence on both seed and oil yield. These increases amounted to $30.20 \%$ and $23.30 \%$ in the first season and $30.40 \%$ and $26.0 \%$ in the second season; data also indicate that increasing 
nitrogen levels from 30 to $90 \mathrm{~kg} / \mathrm{fed}$ resulted decreases in oil \% in seeds in the two seasons.

The decreases in these characters with increasing nitrogen level might be due to role of nitrogen in activating the growth and yield component. These results are in agree- ment with those reported by Naderifar and Daneshian (2012), where they found nitrogen fertilizer had significant effect on the seed number, seed yield, 1000-seed weight and plant height of canola plants. The highest yield was obtained from nitrogen level $150 \mathrm{~kg} / \mathrm{ha}$. treatment.

Table 3. Effect of nitrogen fertilization treatments on yield and its components of canola during 2007-2008 and 2008-2009 growing seasons.

\begin{tabular}{|c|c|c|c|c|c|}
\hline Characters & $\begin{array}{c}\text { Plant } \\
\text { height }(\mathrm{cm})\end{array}$ & $\begin{array}{l}\text { 1000- seed } \\
\text { weight }(\mathrm{g})\end{array}$ & $\begin{array}{r}\text { Seed yield } \\
(\mathrm{kg} / \text { fed. })\end{array}$ & $\begin{array}{c}\text { Oil } \\
\text { in seeds } \\
(\%)\end{array}$ & $\begin{array}{c}\text { Oil yield } \\
\text { (kg/ fed.) }\end{array}$ \\
\hline $\mathbf{N}$ fertilizer & \multicolumn{5}{|c|}{ 2007-2008 season } \\
\hline $30 \mathrm{~kg} \mathrm{~N} / \mathrm{fed}$ & 121.9 & 3.45 & 688.9 & 40.84 & 281.4 \\
\hline $60 \mathrm{~kg} \mathrm{~N} / \mathrm{fed}$ & 134.6 & 4.16 & 808.5 & 40.14 & 324.5 \\
\hline $90 \mathrm{~kg} \mathrm{~N} /$ fed. & 141.8 & 4.28 & 987.6 & 37.16 & 367.0 \\
\hline LSD at $5 \%$ & 2.31 & 0.04 & 12.65 & 0.71 & 9.25 \\
\hline \multicolumn{6}{|c|}{ 2008-2009 season } \\
\hline $30 \mathrm{~kg} \mathrm{~N} / \mathrm{fed}$ & 122.5 & 3.47 & 690.6 & 39.87 & 275.3 \\
\hline $60 \mathrm{~kg} \mathrm{~N} /$ fed. & 135.0 & 4.16 & 806.6 & 39.73 & 320.5 \\
\hline $90 \mathrm{~kg} \mathrm{~N} /$ fed. & 142.0 & 4.31 & 992.6 & 37.50 & 372.2 \\
\hline LSD at $5 \%$ & 2.11 & 0.03 & 12.54 & 1.22 & 13.32 \\
\hline
\end{tabular}

Data in Table (4) show that all studied parameters; plant height, 1000-seed weight, seed yield, oil percent in seeds and oil yield were significantly affected by phosphorus fertilization rates $(0,15$ and $45 \mathrm{~kg}$ $\mathrm{P}_{2} \mathrm{O}_{5} / \mathrm{fed}$ ), applied to canola plants in the two seasons. Increasing phosphorus level from 0 to $45 \mathrm{~kg} \mathrm{P}_{2} \mathrm{O}_{5} /$ fed. led to significant increase in seed yield by $13.4 \%$ and $14.0 \%$ in the first and second season respectively. The highest values of the studied parameters were recorded when the level 45 $\mathrm{kg} \mathrm{P}_{2} \mathrm{O}_{5} /$ fed. was added in the two seasons in comparison to the control (0 kg $\mathrm{P}_{2} \mathrm{O}_{5} /$ fed.). Also, on contrary to nitrogen effect on oil percent, phosphorus addition resulted in increases in oil \% in seeds in the two seasons the phosphorus difficency in the soil (Table 1)(2.3 ppm) is the reasol for the applying $45 \mathrm{~kg} \mathrm{P}_{2} \mathrm{O}_{5} /$ fed. 
Table 4. Effect of phosphorus fertilization treatments on yield and its components of canola during 2007-2008 and 2008-2009 growing seasons.

\begin{tabular}{|c|c|c|c|c|c|}
\hline \multirow{2}{*}{$P$ fertilizer } & $\begin{array}{l}\text { Plant height } \\
\text { (cm) }\end{array}$ & $\begin{array}{l}\text { 1000- seed } \\
\text { weight }(\mathrm{g})\end{array}$ & $\begin{array}{c}\text { Seed yield } \\
(\mathrm{kg} / \mathrm{fed} .)\end{array}$ & $\begin{array}{c}\text { Oil } \\
\text { in seeds }(\%)\end{array}$ & $\begin{array}{l}\text { Oil yield } \\
\text { (kg/ fed.) }\end{array}$ \\
\hline & \multicolumn{5}{|c|}{$2007-2008$ season } \\
\hline $0 \mathrm{~kg} \mathrm{P}_{2} \mathrm{O}_{5} / \mathrm{fed}$ & 128.1 & 3.77 & 771.3 & 36.03 & 277.9 \\
\hline $15 \mathrm{~kg} \mathrm{P}_{2} \mathrm{O}_{5} /$ fed. & 133.0 & 3.97 & 823.5 & 38.30 & 315.4 \\
\hline $45 \mathrm{~kg} \mathrm{P}_{2} \mathrm{O}_{5} /$ fed. & 137.3 & 4.15 & 890.2 & 43.82 & 390.1 \\
\hline LSD at $5 \%$ & 2.55 & 0.04 & 16.32 & 0.86 & 9.20 \\
\hline \multicolumn{6}{|c|}{ 2008-2009 season } \\
\hline $0 \mathrm{~kg} \mathrm{P}_{2} \mathrm{O}_{5} /$ fed. & 127.7 & 3.78 & 768.1 & 35.39 & 271.8 \\
\hline $15 \mathrm{~kg} \mathrm{P}_{2} \mathrm{O}_{5} / \mathrm{fed}$ & 133.0 & 3.98 & 828.3 & 38.75 & 320.9 \\
\hline $45 \mathrm{~kg} \mathrm{P}_{2} \mathrm{O}_{5} /$ fed. & 138.8 & 4.17 & 893.4 & 42.97 & 383.9 \\
\hline LSD at $5 \%$ & 2.06 & 0.04 & 11.89 & 0.82 & 8.52 \\
\hline
\end{tabular}

Data in Table (5) show that the interaction effect of biofertilizer and nitrogen fertilization rates on plant height, 1000-seed weight, seed yield, oil percentage in seed and oil yield was not significant in the two seasons. In the second season, only 1000 -seed weight was significantly affected by the interaction between biofertilizer and nitrogen rates applied to canola plants. The highest values were found when $90 \mathrm{~kg} \mathrm{~N} /$ fed. with added along biofertilizer treatment in both seasons. In the two seasons oil $\%$ in seeds were decreased as nitrogen level increased either with or without biofertilization. Generally, biofertilization accompanied by $\mathrm{N}$ fertilization scored remarkable increments in all parameter studied during the two seasons.

Table 5. Effect of the interaction between bio and nitrogen fertilization treatments on yield and its components of canola during 2007-2008 and 2008-2009 growing seasons.

\begin{tabular}{|c|c|c|c|c|c|c|}
\hline \multirow{2}{*}{\multicolumn{2}{|c|}{$\mathrm{B} \times \mathrm{N}$}} & $\begin{array}{c}\text { Plant } \\
\text { height }(\mathrm{cm})\end{array}$ & $\begin{array}{l}\text { 1000- seed } \\
\text { weight (g) }\end{array}$ & $\begin{array}{c}\text { Seed yield } \\
\text { (kg/ fed.) }\end{array}$ & $\begin{array}{l}\text { Oil } \\
\text { in seeds } \\
(\%)\end{array}$ & $\begin{array}{l}\text { Oil yield } \\
\text { (kg/ fed.) }\end{array}$ \\
\hline & & \multicolumn{5}{|c|}{ 2007-2008 season } \\
\hline \multirow{3}{*}{ 。ำ } & $30 \mathrm{~kg} \mathrm{~N} /$ fed. & 120.9 & 3.42 & 682.1 & 40.09 & 273.5 \\
\hline & $60 \mathrm{~kg} \mathrm{~N} / \mathrm{fed}$. & 134.0 & 4.15 & 809.9 & 39.47 & 319.7 \\
\hline & $90 \mathrm{~kg} \mathrm{~N} / \mathrm{fed}$. & 141.7 & 4.25 & 981.2 & 36.56 & 358.7 \\
\hline \multirow{3}{*}{ 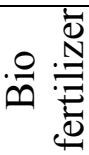 } & $30 \mathrm{~kg} \mathrm{~N} / \mathrm{fed}$. & 122.9 & 3.48 & 695.8 & 41.60 & 289.5 \\
\hline & $60 \mathrm{~kg} \mathrm{~N} / \mathrm{fed}$. & 135.2 & 4.17 & 807.1 & 40.81 & 329.4 \\
\hline & $90 \mathrm{~kg} \mathrm{~N} / \mathrm{fed}$. & 141.9 & 4.31 & 993.9 & 37.76 & 375.3 \\
\hline \multicolumn{2}{|c|}{ LSD at $5 \%$} & N.S. & N.S. & N.S. & N.S. & N.S. \\
\hline \multicolumn{7}{|c|}{ 2008-2009 season } \\
\hline \multirow{3}{*}{ 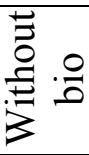 } & $30 \mathrm{~kg} \mathrm{~N} /$ fed. & 121.1 & 3.43 & 683.7 & 39.14 & 367.6 \\
\hline & $60 \mathrm{~kg} \mathrm{~N} / \mathrm{fed}$. & 134.7 & 4.16 & 808.3 & 39.21 & 316.9 \\
\hline & $90 \mathrm{~kg} \mathrm{~N} / \mathrm{fed}$. & 140.8 & 4.26 & 979.6 & 36.82 & 360.7 \\
\hline \multirow{3}{*}{ 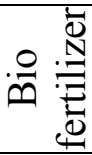 } & $30 \mathrm{~kg} \mathrm{~N} / \mathrm{fed}$. & 124.0 & 3.50 & 697.4 & 40.61 & 283.2 \\
\hline & $60 \mathrm{~kg} \mathrm{~N} / \mathrm{fed}$. & 135.3 & 4.16 & 804.9 & 40.25 & 323.9 \\
\hline & $90 \mathrm{~kg} \mathrm{~N} / \mathrm{fed}$. & 143.1 & 4.35 & 1005.6 & 38.18 & 283.9 \\
\hline \multicolumn{2}{|c|}{ LSD at $5 \%$} & N.S. & 0.03 & N.S. & N.S. & N.S. \\
\hline
\end{tabular}


Regarding the interaction between biofertilizer and phosphorus application; data in Table (6) reveal that all growth parameters, yield and yield components were not significantly affected by bio $\times \mathrm{P}$ interaction effect in the two growing seasons.
The highest values of seed yield (897.4 and $900 \mathrm{~kg} / \mathrm{fed}$.) were obtained when $45 \mathrm{~kg} \mathrm{P}_{2} \mathrm{O}_{5} /$ fed. were added to canola plants fertilized with biofertilizer in the first and the second seasons respectively.

Table 6. Effect of the interaction between bio and phosphorus fertilization treatments on yield and its components of canola during 2007-2008 and 2008-2009 growing seasons

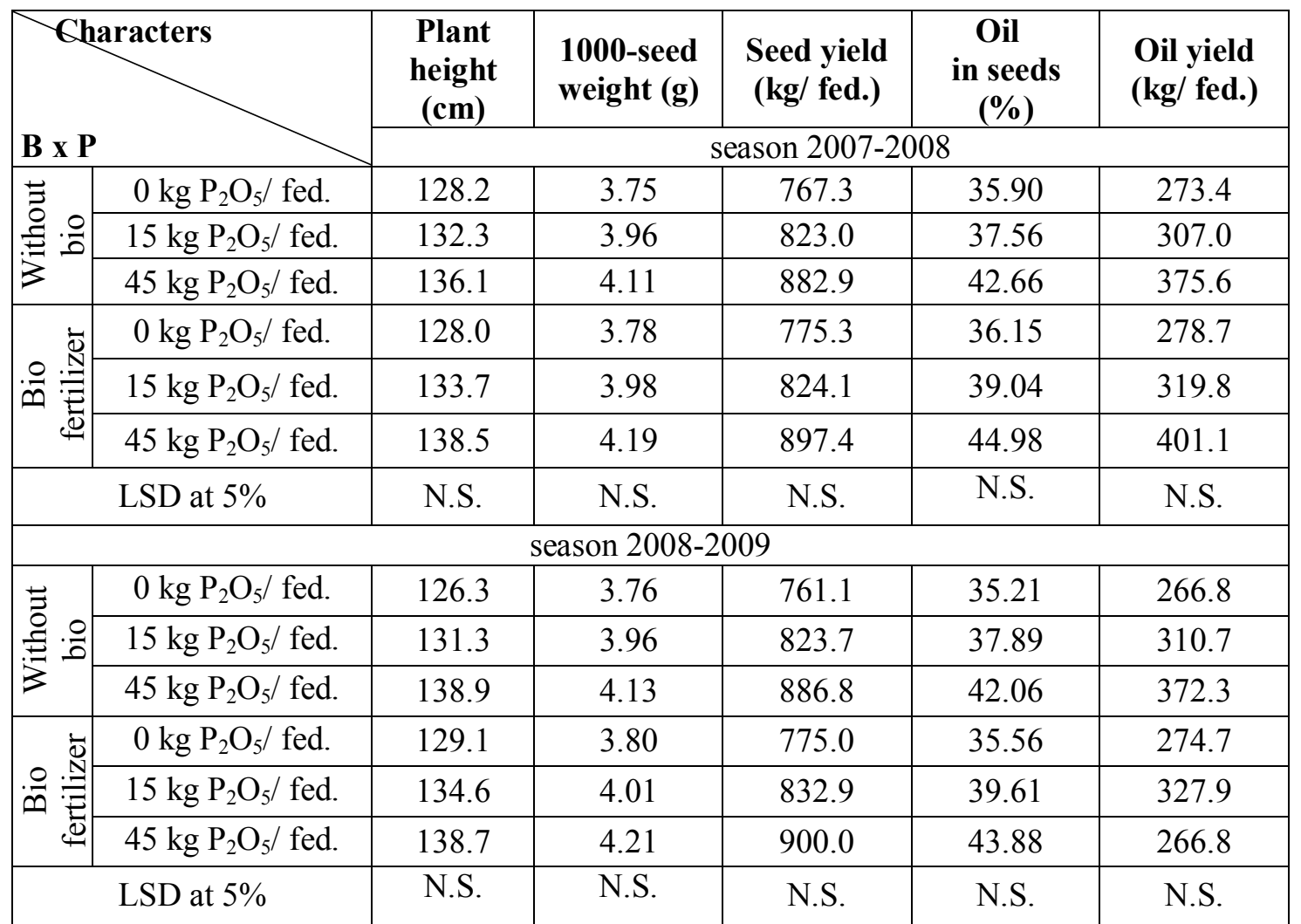

$\mathrm{NS}=$ net significant

The interaction effect between $\mathrm{N} \times \mathrm{P}$ fertilization treatments on growth, yield and yield components of canola during the two seasons 2007 and 2008 was illustrated in Table (7). This interaction showed significant increases in 1000-seed weight, seed yield and oil yield in the two seasons.

On the other hand plant height and oil percentage were not significantly influenced by $\mathrm{N} \times \mathrm{P}$ interaction in the two seasons. However, oil \% was reduced steadly but not signifsanty by $\mathrm{N} \times \mathrm{P}$ inyeraction effect Data also indicate that the highest values of seed yields (1050.6 and $1073 \mathrm{~kg} / \mathrm{fed}$.) were obtained by application of $90 \mathrm{~kg} \mathrm{~N} / \mathrm{fed}$. with $45 \mathrm{~kg}$ $\mathrm{P}_{2} \mathrm{O}_{5} /$ fed. in the first and the second seasons respectively. Also, it is clear that increasing level of phosphorus fertilizer caused remarkable increases in oil percentage in canola seeds in the two seasons. 
Table 7. Effect of the interaction between nitrogen and phosphorus fertilization treatments on yield and its components of canola during 2007-2008 and 20082009 growing seasons

\begin{tabular}{|c|c|c|c|c|c|c|}
\hline \multirow{2}{*}{$\mathbf{N} \times \mathbf{P}$} & \multirow{2}{*}{ Characters } & \begin{tabular}{|c|}
$\begin{array}{c}\text { Plant height } \\
\text { (cm) }\end{array}$ \\
\end{tabular} & $\begin{array}{l}\text { 1000- seed } \\
\text { weight }(g)\end{array}$ & $\begin{array}{c}\text { Seed yield } \\
\text { (kg/ fed.) }\end{array}$ & $\begin{array}{c}\text { Oil } \\
\text { in seeds(\%) }\end{array}$ & $\begin{array}{l}\text { Oil yield } \\
\text { (kg/ fed.) }\end{array}$ \\
\hline & & \multicolumn{5}{|c|}{ 2007-2008 season } \\
\hline \multirow{3}{*}{ 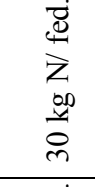 } & $0 \mathrm{~kg} \mathrm{P}_{2} \mathrm{O}_{5} /$ fed. & 115.4 & 3.30 & 623.1 & 37.24 & 232.0 \\
\hline & $15 \mathrm{~kg} \mathrm{P}_{2} \mathrm{O}_{5} /$ fed. & 124.2 & 3.43 & 704.7 & 40.19 & 283.2 \\
\hline & $45 \mathrm{~kg} \mathrm{P}_{2} \mathrm{O}_{5} /$ fed. & 126.2 & 3.61 & 739.0 & 45.10 & 333.3 \\
\hline \multirow{3}{*}{ 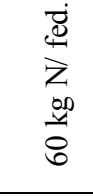 } & $0 \mathrm{~kg} \mathrm{P}_{2} \mathrm{O}_{5} /$ fed. & 129.2 & 3.92 & 761.4 & 37.04 & 282.0 \\
\hline & $15 \mathrm{~kg} \mathrm{P}_{2} \mathrm{O}_{5} /$ fed. & 134.1 & 4.18 & 783.3 & 38.70 & 303.1 \\
\hline & $45 \mathrm{~kg} \mathrm{P}_{2} \mathrm{O}_{5} /$ fed. & 140.6 & 4.38 & 880.8 & 44.70 & 393.7 \\
\hline \multirow{3}{*}{ 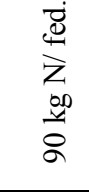 } & $0 \mathrm{~kg} \mathrm{P}_{2} \mathrm{O}_{5} /$ fed. & 139.6 & 4.08 & 929.4 & 33.80 & 314.1 \\
\hline & $15 \mathrm{~kg} \mathrm{P}_{2} \mathrm{O}_{5} /$ fed. & 140.8 & 4.31 & 982.7 & 36.01 & 353.9 \\
\hline & $45 \mathrm{~kg} \mathrm{P}_{2} \mathrm{O}_{5} /$ fed. & 145.0 & 4.46 & 1050.6 & 41.66 & 437.9 \\
\hline \multicolumn{2}{|r|}{ LSD at $5 \%$} & N.S. & 0.05 & 23.44 & N.S. & 19.24 \\
\hline \multicolumn{7}{|c|}{ 2008-2009 season } \\
\hline \multirow{3}{*}{ 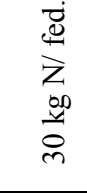 } & $0 \mathrm{~kg} \mathrm{P}_{2} \mathrm{O}_{5} /$ fed. & 113.4 & 3.34 & 627.5 & 36.37 & 228.3 \\
\hline & $15 \mathrm{~kg} \mathrm{P}_{2} \mathrm{O}_{5} /$ fed. & 124.8 & 3.43 & 702.8 & 40.36 & 283.6 \\
\hline & $45 \mathrm{~kg} \mathrm{P}_{2} \mathrm{O}_{5} /$ fed. & 129.4 & 3.63 & 741.5 & 42.90 & 318.1 \\
\hline \multirow{3}{*}{ 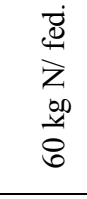 } & $0 \mathrm{~kg} \mathrm{P}_{2} \mathrm{O}_{5} /$ fed. & 131.0 & 3.90 & 758.9 & 35.72 & 271.1 \\
\hline & $15 \mathrm{~kg} \mathrm{P}_{2} \mathrm{O}_{5} /$ fed. & 134.5 & 4.19 & 795.1 & 38.99 & 310.0 \\
\hline & $45 \mathrm{~kg} \mathrm{P}_{2} \mathrm{O}_{5} /$ fed. & 139.5 & 4.38 & 865.8 & 44.48 & 385.1 \\
\hline \multirow{3}{*}{ 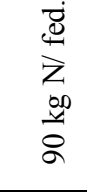 } & $0 \mathrm{~kg} \mathrm{P}_{2} \mathrm{O}_{5} /$ fed. & 138.7 & 4.11 & 917.7 & 34.08 & 312.9 \\
\hline & $15 \mathrm{~kg} \mathrm{P}_{2} \mathrm{O}_{5} /$ fed. & 139.6 & 4.33 & 987.0 & 36.89 & 364.2 \\
\hline & $45 \mathrm{~kg} \mathrm{P}_{2} \mathrm{O}_{5} /$ fed. & 147.6 & 4.48 & 1073.0 & 41.54 & 446.0 \\
\hline & LSD at $5 \%$ & N.S. & 0.07 & 24.86 & N.S. & 14.76 \\
\hline
\end{tabular}

NS $=$ Not significant

\section{References}

Abd El-Gawad, A.M., M.H. Hendawey and H.I.A. Farag, 2009. Interaction Between Biofertilization and Canola Genotypes in Relation to Some Biochemical Constituents under Siwa Oasis Conditions, Res. J. of Agric. and Biolo. Sci, 5(1): 82-96.

Ahmadi, M. and M. J. Bahrani, 2009. Yield and yield components of rapeseed as influenced by water stress at different growth stages and nitrogen levels. American-
Eurasian J. Agric. and Environ. Sci., 5 (6): 755-761.

Brady, N.C., and R.R. Weil. 2002. Soil Phosphorus and Potassium. In: The Nature and Properties of Soils $\left(13^{\text {th }}\right.$ Ed.). Upper Saddle River, NJ: Prentice-Hall, Inc.

Brown J., J.B. Davis, M. Lauver and O. Wysocki, 2008. USCA Canola Growers' Manual. Oregon. P:71.

Fathi G, A. Banisaidy, S.A. Siadat and F. Ebrahimpoor, 2002.Effect of different Levels and plant density on grainy yield of rapeseed, cultiv arpf 7075 in Khuzestan conditions. 
The scientific Journal of Agricultre, 25(1):43-58.

Fathy S. E. and A.B. Ahmed, 2009. Performance of Canola (Brassica napas L.) Seed Yield, Yield Components and Seed Quality under the Effects of Four Genotypes and Nitrogen Fertilizer Rates, JKAU: Met., Env. and Arid Land Agric. Sci., Vol. 20, No. 2, pp: 33-47.

Fatma, A.A. and M.R. Wafaa, 2009. Effect of foliar application with gibberellic acid and urea on growth, yield, seed oil content and its fatty acids of rapeseed. J. Agric .Sci. Mansoura Univ.34 (4):2913-2930.

Freitas J.R., M.R. Banerjee and J.J. Germida, 1997. Phosphatesolubilizing rhizobacteria enhance the growth and yield but not phosphorus uptake of canola (Brassica napus L.). Biol. Fertil. Soils, 24: 358-364.

Gomez, K.A. and A.A. Gomez, 1986. Statistical Procedures for Agricultural Research. $2^{\text {nd }}$ ED., Wiley, New York.

Gupta, A.K., and Samnotra, R.K. 2004. Effect of bio fertilizers and nitrogen on growth, quality and yield of cabbage (Brassica napus L.). Environ. Ecol., 22, 551-553.

Keeney D.R. and D.W. Nelson, 1982. Nitrogen Inorganic Forms. Pages 643-698. In A.L. Page et. al., Eds. Methods of soil analysis. Part2. Agronomy No. 9, Amer. Soc. of Agron., Madison, WI.

Klute, A.A, 1986. Methods of Soil Analysis. Part $12^{\text {nd }}$ ed. American Society of Agronomy .Inc. Publishes, Madison, Wisconsin, USA.

Mohanty S., N.K. Paikaray and Z. Rajan, 2006. Availability and uptake of phosphorus from organic manures in groundnut (Arachis hypogea L.) using radio tracer technique. Geoderma 133:225-230.

Mottalebipour, S. and M.J. Bahrani, 2006. Response of two irrigated rape seed cultivars to plant code for stages of (Brassica napus L.). Asp. Appl. Biol., 93: 221-234.

Naderifar, M and J. Daneshian, 2012. Effect of different nitrogen and biofertilizers effect on growth and yield of Brassica napus L. Intl. J. Agric. Crop Sci., 4(8): 478-482.

Onyers, E.S. and E.O. McLean, 1969. Plant uptake and chemical extractions for evaluating Potassium release characteristics of soils. Soil Sci. Soc. Amer. Proc. 33: 226-230.

Page, A.L.; R.H. Miller and D.R. Keeney 1984. Methods of soil analysis part 2: Chemical and Microbial Properties, $2^{\text {nd }}$ Edition. Agronomy series, 9. Am. Sa. Agron. Inc, Pub., Medes on, Wisconsin, USA.

Shekh, B.A., 2006. Biotechnology and biofertilization: Key to sustainable agriculture. Scientific issue, (1) Das, K., R.Dang, T. N.

Tomm GO, P.E.P. Ferreira, J.L.P. Aguiar, A.M.G. Castro, S.M.V. Lima and C. Mori, 2010. Panorama atual e indicações para aumento de eficiência da produção de canola no Brasil. Embrapa Trigo, Passo fundo. P.82.

Turan. M,N. Ataoglu and F.Sahin. 2006. Evaluation of the capacity of phosphate solubilizing bacteria and fungi on different forms of phosphorus in liquid culture. Sustainable Agric.,28: 99-108. 


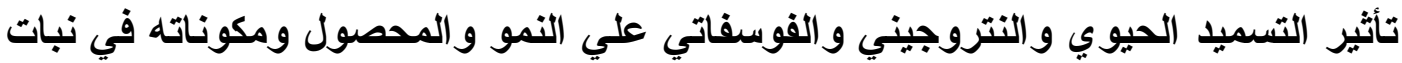

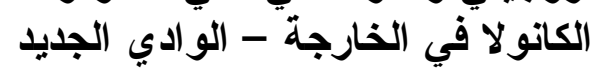

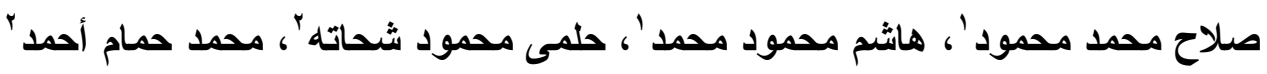

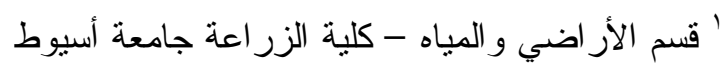

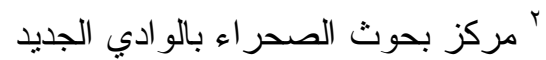

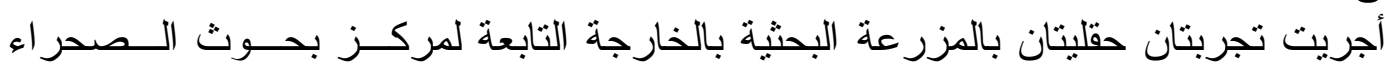

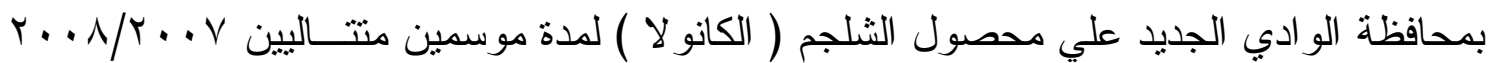

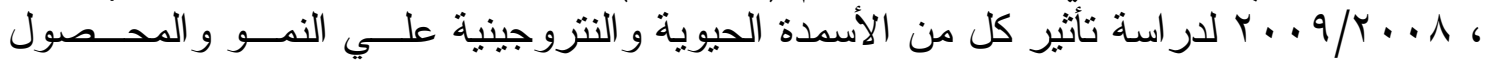

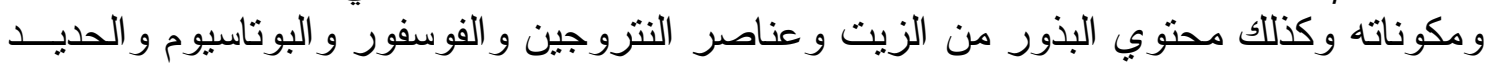

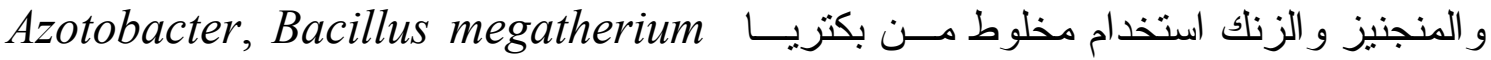

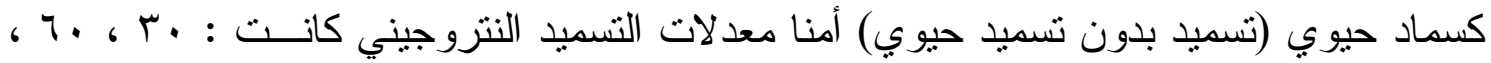

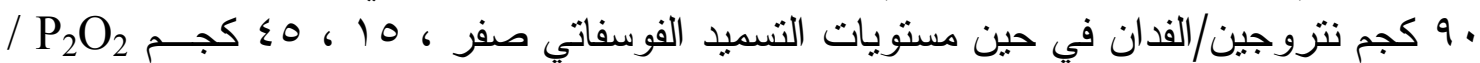

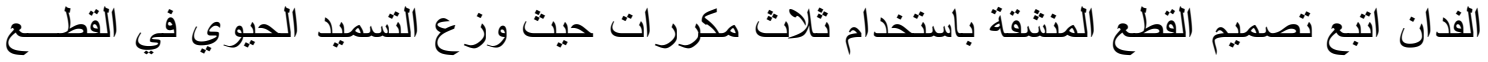
الرئيسية و التسميد النتروجيني في القطع الفر عية و التسميد الفوسفاتي في القطع تحت الفي الفرعية.

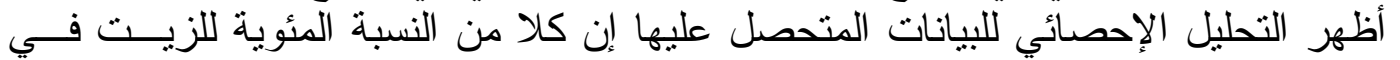

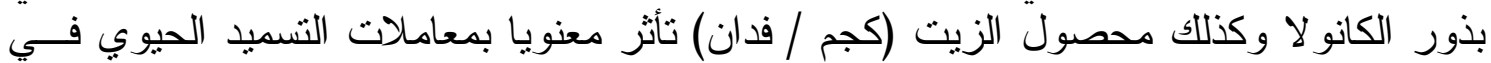

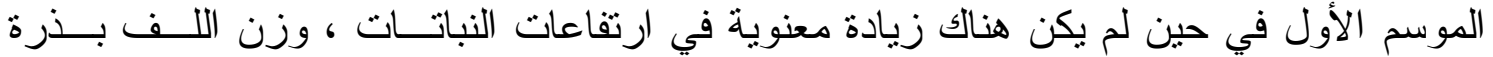
ومحصول البذور في الموسم الثاني.

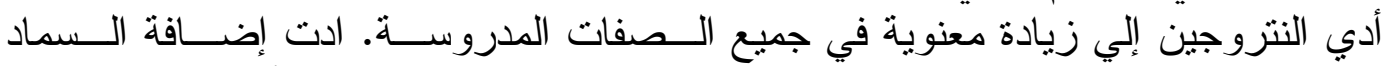

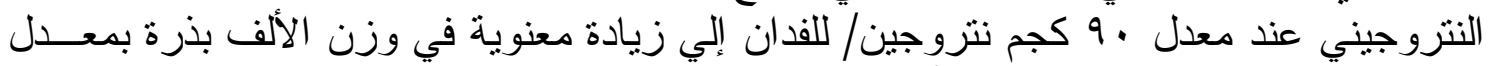

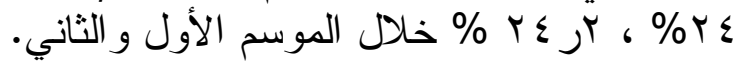

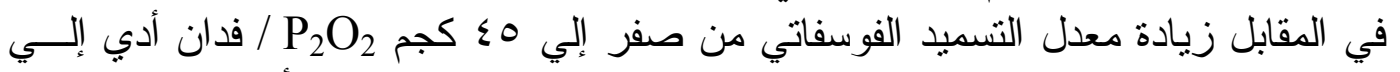

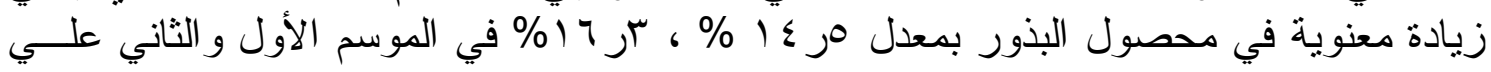

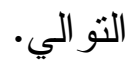

